Article

\title{
Economic Assessment of South African Urban Green Spaces Using the Proximity Principle: Municipal Valuation vs. Market Value
}

\author{
Louis Lategan ${ }^{1, *}$, Juaneé Cilliers ${ }^{2}$, Zinea Huston ${ }^{1}$, Nadia Blaauw ${ }^{1}$ and Sarel Cilliers ${ }^{1}$ \\ ${ }^{1}$ Unit for Environmental Sciences and Management, North-West University, South Africa; \\ E-Mails: latlou.info@gmail.com (L.L.), zineahuston@gmail.com (Z.H.), blaauw.nadia@yahoo.com (N.B.), \\ sarel.cilliers@nwu.ac.za (S.C.) \\ ${ }^{2}$ School of Built Environment, University of Technology Sydney, Australia; E-Mail: juanee.cilliers@uts.edu.au \\ * Corresponding author
}

Submitted: 27 April 2021 | Accepted: 27 July 2021 | Published: 14 October 2021

\begin{abstract}
Urban green spaces (UGSs) deliver ecosystem services and potential economic benefits like increases in proximate residential property prices. The proximity principle (PP) premises that property prices increase as distance to UGS decreases. The PP has generally been confirmed by studies using municipal valuations and market values internationally. Conversely, South African studies have mostly employed municipal valuations and results have rejected the PP. There is an accepted interrelationship, but also often discrepancies, between municipal valuations and market values, presenting scope for this article to explore whether negative results are confirmed when market values replace municipal valuations in PP studies in the South African context. Accordingly, a statistical analysis of market values is completed in the Potchefstroom case study, where five test sites are replicated from studies that employed municipal valuations for longitudinal comparison. Results verify generally higher market values than municipal valuations and confirm the PP in two, but reject the PP in three, of five test sites. Previous studies employing municipal valuations in the case study confirmed the PP in one instance, thus presenting certain, but limited, inconsistencies between findings based on municipal valuation vs. market value. Results suggest that the market's willingness to pay for UGS proximity is sensitive to the ecosystem services and disservices rendered by specific UGS, but not significantly more than reflected in municipal valuations. Overall, findings underscore the need to protect and curate features that encourage willingness to pay for UGS proximity to increase municipal valuations and property taxes to help finance urban greening.
\end{abstract}

\section{Keywords}

green infrastructure; market value; municipal valuation; proximity principle; South Africa; urban green space

\section{Issue}

This article is part of the issue "Towards Green(er) Cities: Contextualizing Green Benefits for Urban Spaces and Contemporary Societies" edited by Juaneé Cilliers (University of Technology Sydney, Australia).

(C) 2021 by the authors; licensee Cogitatio (Lisbon, Portugal). This article is licensed under a Creative Commons Attribution 4.0 International License (CC BY).

\section{Introduction}

Urban green spaces (UGSs) include land parcels of various types located within the urban boundary, covered by permeable surfaces, soil, or flora (Girma et al., 2019 , p. 138). Zoning classifications include residential, recreational, commercial, or agricultural categories to accommodate land uses like communal parks, playgrounds, sport facilities, greenways, green walls and roofs, urban forests, private gardens, wetlands and riparian areas, and street-side vegetation. UGSs may also encompass informal, residual, or unattended parcels, including derelict properties, vacant lots, and spaces along transportation corridors (J. Cilliers, 2013, p. 100; Girma et al., 2019, p. 138). Scholarly interest in UGSs has peaked in recent years, recognising their potential contributions to urban quality of life and service delivery as components of green infrastructure (du Toit et al., 
2018 , p. 249), defined as "the connected network of multifunctional, predominantly unbuilt, spaces that support both ecological and social activities and processes" (Venter et al., 2020, p. 2) to deliver benefits as ecosystem services.

Although academic support for the prioritisation of UGS planning and development is mounting, in practice these spaces are frequently side-lined as a result of the pressures caused by rapid urbanisation and associated land use change and conflict (Garcia-Garcia et al., 2020 , p. 1). In South Africa, UGSs are often outcompeted by land uses deemed more deserving in terms of basic needs, political cachet, or economic potential (Afriyanie et al., 2020, p. 2). Accordingly, natural landscapes and existing UGSs undergo land use conversion, often following official densification strategies or informal land grabs by the destitute (Girma et al., 2019, p. 140; Lategan \& Cilliers, 2016a, p. 15). South Africa's UGSs are particularly vulnerable, considering the country's growing housing backlog and a burgeoning population accommodated in the informal sector (Lategan et al., 2020, p. 2). This is exacerbated in a context where basic service delivery is declining and UGSs are considered luxuries and not necessities by many decisionmakers (Girma et al., 2019, p. 139), even as residents in the Global South may generally depend significantly on certain provisioning and regulating ecosystem services provided by UGSs (see Section 2; Balbi et al., 2019, p. 5; Shackleton, 2021, pp. 217-219). Existing UGSs face additional challenges from inadequate institutional commitment and financial and human capital resources (Chishaleshale et al., 2015, p. 822). Government officials and planning practitioners in South Africa, and beyond, often present limited knowledge regarding green infrastructure and potential UGS contributions (Jacobs, 2019; Van Zyl, 2021). Countless UGSs are furthermore plagued by illegal dumping, pollution, crime, and invasive species that threaten indigenous biodiversity (Lategan \& Cilliers, 2016 b, p. 5). To defend existing greenery and promote the development of more UGSs an argument for the social, environmental, and specifically economic benefits UGSs can deliver must be made. Economic valuation is not intended to commodify greenery and view it solely through a financial lens, but to clarify an important and often misunderstood component of the multiple values presented to inform more balanced decision-making (Boyer \& Polasky, 2004, p. 746; Pascual et al., 2017, p. 9).

This article departs with a review of the ecosystem services and ecosystem disservices potentially delivered by UGSs, emphasising prospective economic contributions. The next sections discuss economic valuation methods, focussing on hedonic price analyses and the proximity principle (PP), which states that property prices will increase as distance to UGS decreases; review findings from relevant studies, showing that South African examples have rejected the PP and have utilised municipal valuations in their investigations; and detail the interrelationship between municipal valuations and market values. The discussion provides scope to explore whether the negative results identified are confirmed when market values replace municipal valuations in PP studies in the South African context. From there, the case study of Potchefstroom, South Africa and the methodology followed in testing the PP based on estimated market values there are explained, before delivering results that inform main conclusions and recommendations.

\section{Urban Green Spaces as Part of Green Infrastructure: Ecosystem Services and Ecosystem Disservices}

UGSs may constitute components of the links and nodes that comprise multifunctional green infrastructure networks (Pauleit et al., 2021) that accommodate urban ecosystems and provide various ecosystem services. These ecosystem services deliver several potential environmental, social, and economic benefits (Grafius et al., 2018, p. 558). Environmental and social benefits are frequently more obvious (Van Oijstaeijen et al., 2020, p. 1) than economic benefits given the complexity of calculating and articulating such values (E. J. Cilliers \& Timmermans, 2013). Identifying economic contributions is vital towards greener planning agendas as decisionmakers require evidence of such offerings to mainstream green infrastructure at strategic management level (Van Oijstaeijen et al., 2020, p. 2), to capitalise on the full range of benefits presented and to address the disadvantages, or ecosystem disservices, potentially rendered. The ecosystem disservices concept recognises that the same ecosystem functions that provide social, environmental, and economic benefits, may render contrasting negative impacts (Davoren \& Shackleton, 2021). Table 1 summarises the ecosystem services and ecosystem disservices concepts.

Many of these ecosystem disservices are prevalent in South Africa, deterring users from accessing facilities and influencing willingness to buy properties in proximity to UGSs (Gómez-Baggethun \& Barton, 2013, p. 238). UGSs are potential hotspots for criminal activity, especially when lushly vegetated, poorly lit, and unmaintained, as is often the case in South Africa (Lategan \& Cilliers, 2016b, P. 9). Such disservices and the others noted above, in conjunction with the restorative power and aesthetic appeal of green views, result in many property owners preferring green vistas (Panduro \& Veie, 2013, p. 126; Sharmin, 2020 , p. 100) and not immediate proximity. Several economic valuation methods of UGSs attempt to account for the complex relationship of push and pull factors that may underpin a cost-benefit analysis of such land uses.

\section{Economic Valuation Methodologies and the Proximity Principle}

Influential economic valuation approaches include the market price method, the replacement/substitute method, contingent valuation, the contingent choice method, benefit transfer, and hedonic pricing (Cilliers 
Table 1. Summary of UGS ecosystem services and disservices.

\begin{tabular}{|c|c|c|}
\hline Categories & Examples of Ecosystem Services & Examples of Ecosystem Disservices \\
\hline Provisioning & $\begin{array}{l}\text { Protection and restoration of natural resources } \\
\text { delivering water, food, medicine, firewood and } \\
\text { material for construction, arts, and crafts. }\end{array}$ & \multirow{4}{*}{$\begin{array}{l}\text { Invasive species outcompete indigenous } \\
\text { species; altered species interactions and } \\
\text { populations; reduced air quality from } \\
\text { production of volatile organic compounds by } \\
\text { plants; urban trees may decrease access to } \\
\text { sunlight; keeping of livestock in urban areas } \\
\text { damages plants and creates unhygienic } \\
\text { conditions; infrastructure damage (e.g., tree } \\
\text { roots that damage roads and kerbs and block } \\
\text { drains and water pipes); maintenance costs for } \\
\text { green infrastructure components and } \\
\text { surrounding buildings; catastrophic effects of } \\
\text { natural disasters such as floods. Security } \\
\text { concerns (shelter for criminals, obscured } \\
\text { views); negative emotions such as discomfort, } \\
\text { anxiety, or fear towards urban animals and } \\
\text { plants; negative health impacts (allergic } \\
\text { reactions); increased noise (e.g., bird and frog } \\
\text { calls); aesthetic impacts (e.g., wild } \\
\text { spontaneous vegetation [weeds]); unpleasant } \\
\text { exposure to the elements (e.g., excessive } \\
\text { winds); safety hazards (e.g., tree falls); } \\
\text { poisonous plants; pests and diseases (Potential } \\
\text { negative impact on property values). }\end{array}$} \\
\hline Regulating & $\begin{array}{l}\text { Improved air and water quality; regulating } \\
\text { urban temperature (reducing the urban heat } \\
\text { island effect); carbon sequestration; waste } \\
\text { water treatment; soil erosion control; } \\
\text { moderation of extreme events (e.g., flooding); } \\
\text { pollination; biological control; replacing } \\
\text { expensive conventional and technical } \\
\text { environmental management systems (e.g., } \\
\text { storm water management, water retention, } \\
\text { microclimate regulation). }\end{array}$ & \\
\hline Supporting & $\begin{array}{l}\text { Enhancing urban biodiversity (urban habitats); } \\
\text { conserving natural ecosystems. }\end{array}$ & \\
\hline Cultural & $\begin{array}{l}\text { Improving mental and physical health; } \\
\text { aesthetic contributions; recreation and } \\
\text { eco-tourism; encouraging social cohesion; } \\
\text { reinforcing cultural heritage and values; } \\
\text { spiritual enrichment; strengthening sense of } \\
\text { place; increase in city liveability and } \\
\text { marketability (Potential increase in property } \\
\text { value and reciprocal increase in property } \\
\text { tax returns). }\end{array}$ & \\
\hline
\end{tabular}

Sources: Own construction from Cilliers and Cilliers (2015, p. 15); S. Cilliers et al. (2013, p. 5); Davoren and Shackleton (2021); du Toit et al. (2018); Grafius et al. (2018, p. 558); Steenkamp et al. (2021).

\& Cilliers, 2015, p. 3). Hedonic price analysis is highlighted for its broad application internationally and in South Africa. Hedonic price analysis considers that residential properties are not homogeneous, but reflect discrete attributions that influence property value that are each studied individually (Daams et al., 2019, p. 389). A prominent example includes proximity to UGS, encapsulated in the PP (Cilliers \& Cilliers, 2015, p. 5), revealing the market's willingness to pay for access to such spaces. Examples of studies are captured in Table 2.

Table 2 demonstrates that the PP has delivered fairly consistent results, depending on the parameters employed and study area identified. The majority of studies have confirmed the PP using market values and not municipal valuations, with the exception of studies based in South Africa.

\section{Municipal Valuation vs. Market Value}

Municipal valuation refers to a value placed on a property by assessors for local authorities as the basis for property taxation as a source of municipal revenue (Cypher \& Hansz, 2003, p. 305; Janssen \& Söderberg, 1999, p. 359). Municipal valuation is bound by set regulations to ensure just outcomes (Ramakhula, 2010, p. 22). In South Africa, the Local Government Municipal Property Rates Act of 2004 regulates local government property taxation and allows for comparative analysis and computer aided mass appraisals (Nyabwengi, 2020, p. 1736). In South Africa, statutory requirements prescribe that municipal values should equal market values, but Ghyoot (2008) observed that valuers often allow for municipal valuations within a $10 \%$ divergence of market values.

Market value refers to the price a property demands in the open market (Malaitham et al., 2020, p. 154), reflecting demand and supply (Das \& Thappa, 2018, p. 15). A property's market value depends on several variables (Das \& Thappa, 2018, p. 16; Janssen \& Söderberg, 1999, p. 359), appraised by a real estate agent or other professionals when properties are put up for sale (Janssen \& Söderberg, 1999, p. 359). Unlike with municipal valuation, the determination of market value may not be bound by regulations but may follow standard approaches such as direct capital comparison, income capitalisation, the cost approach, and residual or developers approach (Das \& Thappa, 2018). Municipal assessors consider the market and professionals and estate agents may use municipal valuations as components in their assessments (Janssen \& Söderberg, 1999 , p. 360). Although determination processes for municipal valuations and market values may differ, they present a complex interrelationship in their shared objective to determine property value (Cypher \& Hansz, 2003, pp. 305-306). 
Table 2. Selected studies employing the PP.

\begin{tabular}{|c|c|c|c|}
\hline Authors & Case Study & $\begin{array}{l}\text { Municipal Valuation/ } \\
\text { Market Value }\end{array}$ & $\begin{array}{l}\text { Proximity } \\
\text { Principle }\end{array}$ \\
\hline Bolitzer and Netusil (2000) & Portland, Oregon, USA & Market value & Confirmed \\
\hline Kim and Johnson (2002) & Corvallis, Oregon, USA & Market value & Confirmed \\
\hline Morancho (2003) & Spain & Market value & Confirmed \\
\hline Tajima (2003) & Boston, Massachusetts, USA & Market value & Confirmed \\
\hline Boyer and Polasky (2004) & Multiple & Market value & Confirmed \\
\hline $\begin{array}{l}\text { Crompton (2005) } \\
\text { v Anderson and West (2006) }\end{array}$ & $\begin{array}{l}\text { Multiple } \\
\text { Minneapolis-St Paul Metro, Minnesota, USA }\end{array}$ & $\begin{array}{l}\text { Market value } \\
\text { Market value }\end{array}$ & $\begin{array}{l}\text { Confirmed } \\
\text { Confirmed }\end{array}$ \\
\hline Dehring and Dunse (2006) & Aberdeen, Scotland & Market value & Confirmed \\
\hline Kong et al. (2007) & Jinan City, China & Market value & Confirmed \\
\hline Conway et al. (2010) & Los Angeles, California, USA & Market value & Confirmed \\
\hline Payton et al. (2008) & Indianapolis/Marion County, Indiana, USA & Market value & Confirmed \\
\hline Arvanitidis et al. (2009) & Several European Cities & Not specified & Confirmed \\
\hline Chen and Jim (2010) & Shenzhen, China & Market values & Confirmed \\
\hline Biao et al. (2012) & Beijing, China & Market value & Confirmed \\
\hline Kovacs (2012) & Portland, Oregon, USA & Market value & Confirmed \\
\hline J. Cilliers (2013) & Potchefstroom, South Africa & Municipal valuation & Rejected \\
\hline Konijnendijk et al. (2013) & Multiple & Market value & Confirmed \\
\hline Panduro and Veie (2013) & Aalborg, Denmark & Market value & Confirmed \\
\hline Gibbons et al. (2014) & England & Market value & Confirmed \\
\hline Cilliers and Cilliers (2015) & Potchefstroom, South Africa & Municipal valuation & Rejected \\
\hline Wen et al. (2015) & Hangzhou, China & Market value & Confirmed \\
\hline Loret de Mola et al. (2017) & $\begin{array}{l}\text { Bogotá, Colombia; Buenos Aires, Argentina; } \\
\text { Lima, Peru; Mexico City, Mexico; } \\
\text { and Santiago, Chile }\end{array}$ & $\begin{array}{l}\text { Market value } \\
\text { (real estate data at } \\
\text { district level) }\end{array}$ & Confirmed \\
\hline Chen and Li (2018) & Guangzhou, China & Market value & Confirmed \\
\hline Immergluck and Balan (2018) & Atlanta, Georgia, USA & Market value & Confirmed \\
\hline Daams et al. (2019) & Amsterdam, the Netherlands & Market value & Confirmed \\
\hline Czembrowski et al. (2019) & Stockholm, Sweden & Market value & Confirmed \\
\hline Combrinck et al. (2020) & Potchefstroom, South Africa & Municipal valuation & Rejected \\
\hline Sharmin (2020) & Dhaka, Bangladesh & Market value & Confirmed \\
\hline Samad et al. (2020) & Kuala Lumpur, Malaysia & Market value & Confirmed \\
\hline Yu et al. (2020) & Shenzhen, China & Rental market value & Confirmed \\
\hline
\end{tabular}

It is widely recognised that valuations and actual market values rarely coincide (Babawale, 2013, p. 387). Various cases of municipal valuations being both lower and higher than estimated market values, or reaslised sales prices, have been reported (Ghyoot, 2008; Ntuli, 2019; Sokutu, 2021). In cases of the latter, allowing for processes of appeal, but in cases of the first, rarely resulting in objections due to lower property taxes due by owners. The question is not necessarily if there is a difference, but rather to what extent the difference between municipal valuations and market values are manifested. In line with the focus of this article, Malaitham et al. (2020, p. 154) suggest that there is uncertainty regard- ing the impact of municipal valuation vs. market value in studies on the PP and UGS, as limited studies have been conducted to compare findings using both as variables. The following section elaborates on the choice of case study for this research and discusses the methodology employed to address the issues raised in the literature review.

\section{Case Study and Methodology}

Potchefstroom, South Africa $\left(26^{\circ} 42^{\prime} 53^{\prime \prime} \mathrm{S}, 27^{\circ} 05^{\prime} 49^{\prime \prime} \mathrm{E}\right)$ was selected as case study based on the previous studies completed there by Cilliers and Cilliers (2015) and 
Combrinck et al. (2020; see Table 2) who investigated the PP by examining sites in five upper middle- to highincome neighbourhoods where a central public UGS and surrounding detached dwellings provided a research sample. Sample areas were categorised within socioeconomic status levels of four and five, thus presenting shared characteristics in accordance with middleto high-income earners in terms of employment status, household size, number of rooms occupied, access to basic services, and schooling status (Lubbe et al., 2010, p. 2903). Owing to this status, UGSs in the sample were fairly well-maintained as a result of both public and private ownership and management and presented significant plant diversity and species richness compared to those in lower income areas (Lubbe, 2011, p. 37). In keeping with Combrinck et al. (2020), test sites included UGSs and surrounding properties in Grimbeek Park, bordering a golf course and areas used for birdwatching and horseback riding; van der Hoff Park, bordering an equestrian open space and wetlands with high biodiversity; Heilige Akker, bordering the sporting grounds of a local university and presenting limited vegetation and tree cover; Oewersig, with dense vegetation bordering the Mooi River and surrounding open space; and next to the Potchefstroom Dam with dense vegetation and tree cover (Cilliers \& Cilliers, 2015; Combrinck et al., 2020). Properties within each sample area were divided into three zones depending on distance to an UGS. Properties in Zone 1 were situated directly adjacent to an UGS; those in Zone 2 were further away, mostly across the street from those in Zone 1; and Zone 3 properties were further away from the UGS, mostly located in the same block, or one street away from those in Zone 2. All properties included ranged between $1,000 \mathrm{~m}^{2}$ to $2,000 \mathrm{~m}^{2}$ in size, with a limited number presenting sizes below or above these parameters. Sample properties were furthermore endowed with ample private UGS, in keeping with expectations for detached properties at this socioeconomic status level. Despite international evidence to the contrary (Dehring \& Dunse, 2006, p. 565), Lategan and Cilliers (2016b) found that in South Africa, the availability of private UGS did not necessarily compensate for public UGS as private UGSs cannot fulfil the multiple functions of public spaces, specifically related to cultural ecosystem services, as part of local heritage and neighbourhood identity, as venues of communal gathering and social interaction or in terms of amenities provided. Several studies have commented on the impacts of location, density, UGS type, size, and quality as well as the availability of private UGS on proximate property values in relation to public UGSs (e.g., Anderson \& West, 2006; Konijnendijk et al., 2013; Sharmin, 2020), with the majority generally confirming the PP internationally (see Table 2).

This research is primarily interested in the degree to which public UGSs are valued in South Africa in fairly homogenous neighbourhoods and if and how such trends fluctuate when employing estimated mar- ket values vs. municipal valuations. Combrinck et al. (2020) employed average price per square metre in South African Rand for each property in the sample derived from 2019 municipal valuations. This article compared these values to estimated market values for the same properties gathered in 2020. Market values were obtained from a reputable international real estate agency's Potchefstroom branch who based its market valuations on four sources. Firstly, "Revolution" software that triangulates inputs by agents from the last 15 years and makes a comparison based on property characteristics. Secondly, "Lightstone" software, which collaborates with South Africa's deeds offices and provides a mean property price compared to others of approximately the same size in the area. Thirdly, the latest municipal valuation role was consulted as part of standard practice. Lastly, the agency drew on the professional discretion of its agents as property experts.

Descriptive statistics were used to report municipal valuations for each property per square metre and compare these values with 2019 municipal valuations. A dependent t-test compared 2019 municipal valuations and 2020 market value estimates. This was followed by analysis of variance (ANOVA) and Kruskal-Wallis tests to determine whether a practically significant difference existed between the delineated zones. Where results differed, the non-parametric test (Kruskal-Wallis) was preferred. This research replicates the methodologies employed by Cilliers and Cilliers (2015) and Combrinck et al. (2020) in recognition of their scientific contributions and for the purpose of direct longitudinal comparison. This article should thus not be regarded as a critique of previous studies, Combrinck et al. (2020) in particular, but as an attempt to expand existing knowledge and deepen understanding of the South African exceptionalism exhibited in Table 2.

\section{Results}

The 2019 municipal valuations observed were $28 \%$ lower than 2020 market value estimates. This represents a considerable difference from standard deviation guidelines, often set at between 5\% and 10\% (Babawale, 2013, p. 396; Hager \& Lord, 1985). For contextualisation, when further compared to a general increase of $14,73 \%$ identified in average residential sale prices realised for detached properties in Potchefstroom during the same period (2019 to 2020) (Property24, 2021), findings thus represent a disproportional and significant difference. Table 3 captures these values and summarises the outcome of the dependent t-test. An effect size of $\approx 0.2$ indicates a small, no practically significant difference; an effect size of $\approx 0.5$ indicates a medium, practically significant difference; and an effect size of $\approx 0.8$ indicates a large, practically significant difference.

Results indicate an overall large practically significant difference $(\approx 0.8)$ between municipal valuations and market value estimates. Market value estimates were 
Table 3. Dependent t-test results.

\begin{tabular}{|c|c|c|c|c|c|c|c|c|}
\hline \multirow[t]{2}{*}{ Area } & \multirow[t]{2}{*}{ Zone } & \multirow{2}{*}{$\begin{array}{c}\mathrm{N} \\
(188)\end{array}$} & \multirow{2}{*}{$\begin{array}{l}\text { Municipal } \\
\text { Valuation } \\
\text { in South } \\
\text { African } \\
\text { Rand } / \mathrm{m}^{2}\end{array}$} & \multirow{2}{*}{$\begin{array}{l}\text { Market } \\
\text { Value } \\
\text { in South } \\
\text { African } \\
\text { Rand } / \mathrm{m}^{2}\end{array}$} & \multirow{2}{*}{$\begin{array}{l}\text { Municipal } \\
\text { Standard } \\
\text { Deviation }\end{array}$} & \multirow{2}{*}{$\begin{array}{l}\text { Market } \\
\text { Standard } \\
\text { Deviation }\end{array}$} & \multirow{2}{*}{$\begin{array}{l}\text { Effect Size } \\
a \approx 0,2 \text { small } \\
b \approx 0,5 \text { medium } \\
c \approx 0,8 \text { large }\end{array}$} & \multirow[b]{2}{*}{$\begin{array}{l}\quad \text { T-test } \\
\text { Statistically } \\
\text { significant } \\
\text { difference } \\
\text { between } \\
\text { municipal and } \\
\text { market }(p<0,05)\end{array}$} \\
\hline & & & & & & & & \\
\hline \multirow[t]{3}{*}{ Grimbeek Park } & 1 & 14 & $1,260.7$ & $1,252.91$ & 237.61 & 375.85 & $0,02 a$ & 0,941 \\
\hline & 2 & 14 & $1,611.67$ & $1,584.32$ & 295.96 & 421.64 & $0,06 b$ & 0,668 \\
\hline & 3 & 13 & $1,699.25$ & $1,493.18$ & 269.72 & 208.74 & $0,76 c$ & 0,019 \\
\hline van der Hoff & 1 & 15 & $1,290.59$ & $1,683.48$ & 341.15 & 753.19 & $0,52 b$ & 0,016 \\
\hline \multirow[t]{2}{*}{ Park } & 2 & 15 & $1,472.43$ & $1,579.05$ & 237.86 & 224.65 & $0,45 b$ & 0,143 \\
\hline & 3 & 13 & $1,624.3$ & $1,902.34$ & 279 & 339.58 & $0,82 c$ & 0 \\
\hline \multirow[t]{3}{*}{ Heilige Akker } & 1 & 10 & $1,751.96$ & $2,299.21$ & 353.01 & 631.25 & $0,87 c$ & 0,012 \\
\hline & 2 & 12 & $1,904.15$ & $2,692.38$ & 280.09 & 858.19 & $0,92 c$ & 0,005 \\
\hline & 3 & 14 & $1,850.28$ & $1,930.69$ & 757.54 & 356.16 & $0,19 a$ & 0,603 \\
\hline \multirow[t]{3}{*}{ Oewersig } & 1 & 14 & $1,668.44$ & $2,355.76$ & 338.6 & 642.54 & $1,07 c$ & 0 \\
\hline & 2 & 14 & $1,852.15$ & $2,480.35$ & 360.64 & 876.91 & $0,72 c$ & 0,031 \\
\hline & 3 & 13 & $1,549.2$ & $2,037.73$ & 415.18 & 255.85 & $1,52 c$ & 0 \\
\hline Potchefstroom & 1 & 9 & $1,116.44$ & $2,139.69$ & 336.36 & $1,213.69$ & $0,84 c$ & 0,019 \\
\hline \multirow[t]{2}{*}{ Dam } & 2 & 9 & $1,303.45$ & $2,223.11$ & 421.46 & 408.47 & $2,25 c$ & 0,001 \\
\hline & 3 & 9 & $1,448.64$ & $2,308.59$ & 421.61 & $1,009.9$ & $0,85 c$ & 0 \\
\hline
\end{tabular}

significantly higher than municipal valuations in four of five test sites, with the exception of Grimbeek Park. Figure 1 illustrates the differences captured in Table 3 regarding fluctuations from Zone 1 to Zone 3 in each test site.

In Grimbeek Park, results presented a general rejection of the PP from Zone 1 to 3 , but confirmed the principle between Zones 2 and 3 with regard to estimated market values. Findings differed slightly in that municipal valuations showed a consistent upward trajectory to reject the PP from Zone 1 to 3. In van der Hoff Park, the PP was confirmed between Zone 1 and Zone 2, but rejected between Zones 1 and 3 . Thus, differing slightly from municipal valuation findings that showed a consistent upward trajectory, but confirming findings on a rejection of the PP in general terms. In Heilige Akker, the PP was rejected between Zone 1 and Zone 2, but confirmed for Zone 1 to Zone 3. Findings concurred with data from municipal valuations showing a peak in Zone 2, but departed where the PP was rejected. For Oewersig, data rejected the PP between Zone 1 and Zone 2, but confirmed the principle for Zone 1 to Zone 3. Results were mirrored in municipal valuations. For Potchefstroom Dam, Zone 3 presented a higher market value estimate than Zone 2 and Zone 1, resulting in a rejection of the PP. This trend echoed findings derived from municipal valuations.

Statistical substantiation to the findings above were provided via ANOVA and Kruskal-Wallis testing using 2020 market value estimates. For ANOVA an effect size of $\approx 0.2$ indicates a small, no practically significant difference; an effect size of $\approx 0.5$ indicates a medium, practically visible difference; and an effect size of $\approx 0.8$ indicates a large, practically significant difference. For the Kruskal-Wallis test, an effect size of $\approx 0.1$ indicates a small or no practically significant difference; an effect size of $\approx 0.3$ indicates a medium or practically visible difference; and an effect size of $\approx 0.5$ indicates a large or practically significant difference. Results are captured in Table 4.

The results from the Kruskal-Wallis test were preferred when the outcomes of statistical tests differed. This is also reflected in Table 5 that summarises complete results in conjunction with Combrinck et al.'s (2020) main findings.

\section{Conclusions}

Municipal valuations were considerably lower than estimated market values in almost all test sites and a large practically significant difference could be established; in general, by a significant $28 \%$, which is well above accepted standards of deviation. Grimbeek Park presented an interesting case, as the only example in which municipal valuations exceeded estimated market values. It falls beyond the scope of this article to investigate the reasons behind this and opportunities for further research are thus presented. As a point of departure for future investigations, it is interesting to note that in a review of the five test sites included in this research, 


\section{COGITATIO}

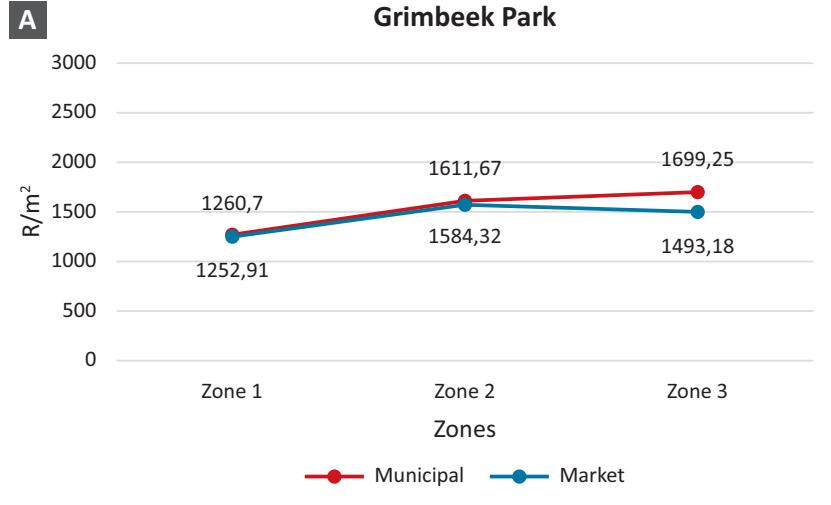

c

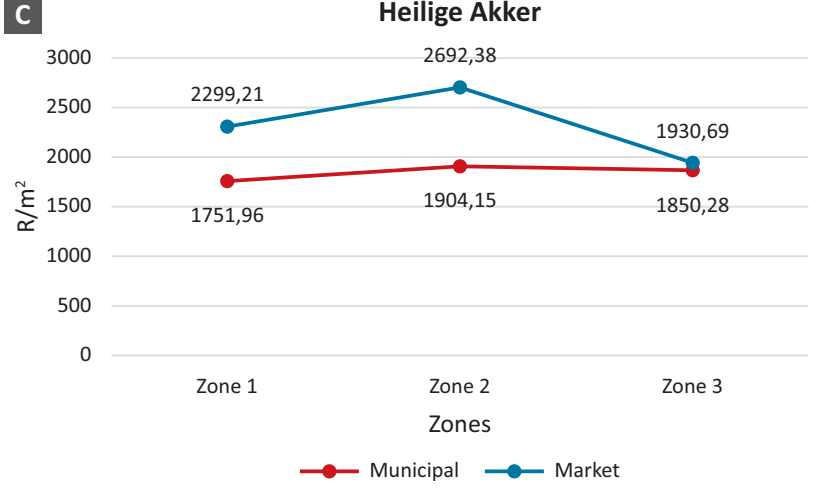

E

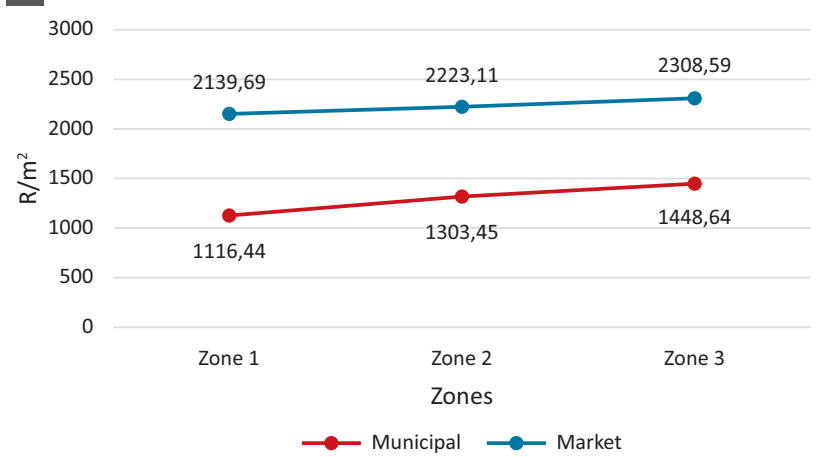

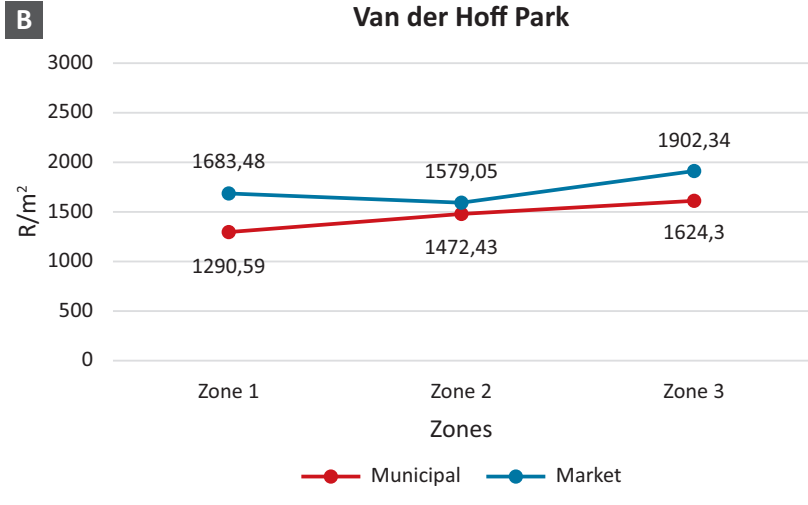

D Oewersig

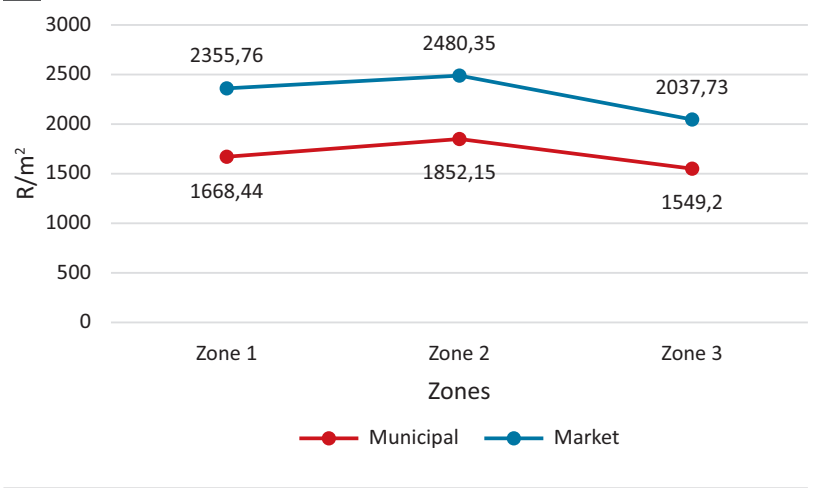

Figure 1. Mean South African Rand $/ \mathrm{m}^{2}$ municipal valuation and estimated market values for the Potchefstroom sample.

based on attributes related to UGSs and the environmental, social, and economic benefits (as ecosystem services) offered, Combrinck (2020) found that Grimbeek Park's UGS delivered the highest overall scores. As a supplementary consideration, the UGS in Grimbeek Park presented the only example of a golf course. Several international studies have indicated that golf courses specifically increase proximate property values at significant levels (Crompton \& Nicholls, 2020; Nicholls \& Crompton, 2007; Yates \& Cowart, 2019).

Another interesting observation relates to the zone in which values reached a peak in each test site. Using municipal valuations, Combrinck et al. (2020) established peaks in Zone 1 in no test sites; peaks in Zone 2 in two test sites (Heilige Akker and Oewersig); and peaks in Zone 3 in three test sites (Grimbeek Park, van der Hoff
Park, and Potchefstroom Dam). In contrast, estimated market values delivered peaks in Zone 1 for no test sites (yet, in van der Hoff Park Zone 1 presented a higher estimate than Zone 2); peaks in Zone 2 for three test sites (Grimbeek Park, Heilige Akker, and Oewersig); and peaks in Zone 3 for two test sites (van der Hoff Park and Potchefstroom Dam). Peaks were thus registered significantly differently using municipal valuation vs. estimated market value.

The absence of peaks in Zone 1 in both data sets, even where the PP was confirmed (Heilige Akker and Oewersig) underscores the negative impacts of adjacency to UGS in South Africa, ascribed to ecosystem disservices such as crime, a lack of maintenance, and other nuisance factors (see Davoren \& Shackleton, 2021 and Table 1). The presence of a higher market value 
Table 4. ANOVA and Kruskal-Wallis testing.

\begin{tabular}{|c|c|c|c|c|c|c|c|c|c|c|}
\hline \multirow[t]{3}{*}{ Area } & \multirow[t]{3}{*}{ Zone } & \multirow{3}{*}{$\begin{array}{c}\mathrm{N} \\
(188)\end{array}$} & \multirow{3}{*}{$\begin{array}{l}\text { Market } \\
\text { Value in } \\
\text { South } \\
\text { African } \\
\text { Rand/m² }\end{array}$} & \multirow{3}{*}{$\begin{array}{l}\text { Standard } \\
\text { Deviation }\end{array}$} & \multicolumn{4}{|c|}{ Effect Size } & \multirow{3}{*}{$\begin{array}{l}\quad \text { ANOVA } \\
\text { Statistically } \\
\text { significant } \\
\text { difference } \\
\text { between } \\
\text { means } \\
(p<0,05)\end{array}$} & \multirow{3}{*}{$\begin{array}{l}\begin{array}{c}\text { Kruskal- } \\
\text { Wallis }\end{array} \\
\text { Statistically } \\
\text { significant } \\
\text { difference } \\
\text { between } \\
\text { mean } \\
\text { ranks } \\
(p<0,05)\end{array}$} \\
\hline & & & & & \multicolumn{2}{|c|}{$\begin{array}{l}\text { ANOVA } \\
\mathrm{a} \approx 0,2 \text { small } \\
\mathrm{b} \approx 0,5 \text { medium } \\
\mathrm{c} \approx 0,8 \text { large }\end{array}$} & \multicolumn{2}{|c|}{$\begin{array}{l}\text { Kruskal-Wallis } \\
\mathrm{a} \approx 0,1 \text { small } \\
\mathrm{b} \approx 0,3 \text { medium } \\
\mathrm{c} \approx 0,5 \text { large }\end{array}$} & & \\
\hline & & & & & 1 with... & 2 with... & 1 with... & 2 with... & & \\
\hline \multirow[t]{3}{*}{ Grimbeek Park } & 1 & 14 & $1,252.91$ & 375.85 & & & & & & \\
\hline & 2 & 14 & $1,584.32$ & 421.64 & $0.79 c$ & & $0,373 b$ & & 0,047 & 0,057 \\
\hline & 3 & 13 & $1,493.18$ & 208.74 & $0.64 b$ & $0.22 a$ & $0,411 b$ & $0,028 a$ & & \\
\hline \multirow{3}{*}{$\begin{array}{l}\text { van der Hoff } \\
\text { Park }\end{array}$} & 1 & 15 & $1,683.48$ & 753.19 & & & & & & \\
\hline & 2 & 15 & $1,579.05$ & 224.65 & $0,14 a$ & & $0,140 a$ & & 0,237 & 0,022 \\
\hline & 3 & 13 & $1,902.34$ & 339.58 & $0,29 a$ & $0,95 c$ & $0,440 c$ & $0,457 c$ & & \\
\hline \multirow[t]{3}{*}{ Heilige Akker } & 1 & 10 & 2,299.21 & 631.25 & & & & & & \\
\hline & 2 & 12 & $2,692.38$ & 858.19 & $0,46 b$ & & $0,197 a$ & & 0,017 & 0,011 \\
\hline & 3 & 14 & $1,930.69$ & 356.16 & $0,58 b$ & $0,89 c$ & $0,287 b$ & $0,615 c$ & & \\
\hline \multirow[t]{3}{*}{ Oewersig } & 1 & 14 & $2,355.76$ & 642.54 & & & & & & \\
\hline & 2 & 14 & $2,480.35$ & 876.91 & $0,14 a$ & & $0,052 a$ & & 0,208 & 0,35 \\
\hline & 3 & 13 & $2,037.73$ & 255.85 & $0,49 b$ & $0,50 b$ & $0,224 a$ & $0,252 b$ & & \\
\hline \multirow{3}{*}{$\begin{array}{l}\text { Potchefstroom } \\
\text { Dam }\end{array}$} & 1 & 9 & $2,139.69$ & $1,213.69$ & & & & & & \\
\hline & 2 & 9 & $2,223.11$ & 408.47 & $0,07 a$ & & $0,468 c$ & & 0,93 & 0,203 \\
\hline & 3 & 9 & $2,308.59$ & 1,009.9 & $0,14 a$ & $0,08 a$ & $0,177 a$ & $0,135 a$ & & \\
\hline
\end{tabular}

estimate in Zone 1 than Zone 2 in van der Hoff Park and more peaks in Zone 2 than Zone 3, when contemplating estimated market value vs. municipal valuation, indicate that whilst immediate adjacency is not always valued, some proximity to UGSs may be appreciated to capitalise on ecosystem services (see Escobedo, 2021, p. 227, and Table 1) and reduce the potential impacts of ecosystem disservices, despite the presence of domestic UGSs. This may also relate to the impacts of visual access to public greenery that present pleasant vistas or offer amenities (Panduro \& Veie, 2013, p. 126; Sharmin, 2020). Although the aim of this study was not to determine to what extent the market's willingness to pay is sensitive to the ecosystem services and ecosystem disservices produced by specific UGSs, the importance of acknowledging these aspects is emphasised in the literature (Davoren \& Shackleton, 2021).

The results in Figure 1, together with the average medium practically significant differences established from zone to zone, confirmed the PP in two test sites using estimated market values compared to one when employing municipal valuations. These are not overwhelming contrasts, but preliminary findings indicate that the relationship between UGS proximity and willing- ness to pay for proximity may be less clear-cut and linear in South Africa than previously reported based on municipal valuations (Cilliers \& Cilliers, 2015; Combrinck et al., 2020). Results still contrast with international norms on the general confirmation of the PP using estimated market values as variables. These preliminary findings suggest that the influence of the variable employed (municipal valuation vs. market value) can thus potentially be disregarded as an explanation for exceptions identified in previous South African-based research on the PP (Table 2).

Although efforts to quantify the value of UGSs have increased, more research is needed in the Global South to provide case studies to guide context-based planning (S. S. Cilliers et al., 2021) and clarify the relationship between UGS proximity and willingness to pay. Future studies may compare municipal valuations and market value estimates on a larger scale in various sites and may consider the physical attributes and specific ecosystem services and ecosystem disservices rendered by individual UGSs through more qualitative approaches to address certain limitations of this research. The complexity of developing integrated urban planning and management systems focusing on ecosystem services and 
Table 5. Comparative summary of results.

\begin{tabular}{|c|c|c|c|c|c|c|c|c|c|c|c|c|c|}
\hline \multirow[b]{2}{*}{ Test Site } & \multirow[b]{2}{*}{$\begin{array}{l}\text { Estimated } \\
\text { market } \\
\text { value } \\
\text { higher } \\
\text { than } \\
\text { municipal } \\
\text { valuation }\end{array}$} & \multicolumn{6}{|c|}{ Municipal Valuation (2019) } & \multicolumn{6}{|c|}{ Estimated Market Value (2020) } \\
\hline & & $\begin{array}{l}\text { Zone } 1 \\
\text { vs. } \\
\text { Zone } 2\end{array}$ & $\begin{array}{l}\text { Zone } 2 \\
\text { vs. } \\
\text { Zone } 3\end{array}$ & $\begin{array}{l}\text { Zone } 1 \\
\text { vs. } \\
\text { Zone } 3\end{array}$ & $\begin{array}{l}\text { PP from } \\
\text { zone to } \\
\text { zone }\end{array}$ & $\begin{array}{l}\text { General } \\
\text { effect } \\
\text { size (non- } \\
\text { parametric } \\
\text { test) }\end{array}$ & $\begin{array}{l}\text { Verdict PP } \\
\text { based on } \\
\text { municipal } \\
\text { valuation }\end{array}$ & $\begin{array}{l}\text { Zone } 1 \\
\text { vs. } \\
\text { Zone } 2\end{array}$ & $\begin{array}{l}\text { Zone } 2 \\
\text { vs. } \\
\text { Zone } 3\end{array}$ & $\begin{array}{l}\text { Zone } 1 \\
\text { vs. } \\
\text { Zone } 3\end{array}$ & $\begin{array}{l}\text { PP from } \\
\text { zone to } \\
\text { zone }\end{array}$ & $\begin{array}{l}\text { General } \\
\text { effect } \\
\text { size (non- } \\
\text { parametric } \\
\text { test) }\end{array}$ & $\begin{array}{l}\text { Verdict PP } \\
\text { (estimated } \\
\text { market } \\
\text { value) }\end{array}$ \\
\hline $\begin{array}{l}\text { Grimbeek } \\
\text { Park }\end{array}$ & No & Lower & Lower & $\begin{array}{l}\text { Lower } \\
\text { (Zone } 3 \\
\text { peak) }\end{array}$ & $\begin{array}{l}\text { Rejected } \\
\text { (Zone } 1 \text { to 3) }\end{array}$ & Large & Rejected & Lower & $\begin{array}{l}\text { Higher } \\
\text { (Zone } 2 \\
\text { peak) }\end{array}$ & Lower & $\begin{array}{l}\text { Confirmed } \\
\text { (Zone } 2 \text { to } 3 \text { ) } \\
\text { Rejected } \\
\text { (Zone } 1 \text { to } 3 \text { ) }\end{array}$ & Medium & Rejected \\
\hline $\begin{array}{l}\text { van der Hoff } \\
\text { Park }\end{array}$ & Yes & Lower & Lower & $\begin{array}{l}\text { Lower } \\
\text { (Zone } 3 \\
\text { peak) }\end{array}$ & $\begin{array}{l}\text { Rejected } \\
\text { (Zone } 1 \text { to 3) }\end{array}$ & Medium & Rejected & Higher & Lower & $\begin{array}{l}\text { Lower } \\
\text { (Zone } 3 \\
\text { peak) }\end{array}$ & $\begin{array}{l}\text { Confirmed } \\
\text { (Zone } 1 \text { to } 2 \text { ) } \\
\text { Rejected } \\
\text { (Zone } 1 \text { to } 3 \text { ) }\end{array}$ & Medium & Rejected \\
\hline Heilige Akker & Yes & Lower & $\begin{array}{l}\text { Higher } \\
\text { (Zone } 2 \\
\text { peak) }\end{array}$ & Lower & $\begin{array}{l}\text { Rejected } \\
\text { (Zone } 1 \text { to 3) }\end{array}$ & Small & Rejected & Lower & $\begin{array}{l}\text { Higher } \\
\text { (Zone } 2 \\
\text { peak) }\end{array}$ & Higher & $\begin{array}{l}\text { Rejected } \\
\text { (Zone } 1 \text { to } 2 \text { ) } \\
\text { Confirmed } \\
\text { (Zone } 1 \text { to } 3 \text { ) }\end{array}$ & Medium & Confirmed \\
\hline Oewersig & Yes & Lower & $\begin{array}{l}\text { Higher } \\
\text { (Zone } 2 \\
\text { peak) }\end{array}$ & Higher & $\begin{array}{l}\text { Confirmed } \\
\text { (Zone } 1 \text { to } 3 \text { ) }\end{array}$ & Medium & Confirmed & Lower & $\begin{array}{l}\text { Higher } \\
\text { (Zone } 2 \\
\text { peak) }\end{array}$ & Higher & $\begin{array}{l}\text { Rejected } \\
\text { (Zone } 1 \text { to } 2 \text { ) } \\
\text { Confirmed } \\
\text { (Zone } 1 \text { to } 3 \text { ) }\end{array}$ & Small & Confirmed \\
\hline $\begin{array}{l}\text { Potchefstroom } \\
\text { Dam }\end{array}$ & Yes & Lower & Lower & $\begin{array}{l}\text { Lower } \\
\text { (Zone } 3 \\
\text { peak) }\end{array}$ & $\begin{array}{l}\text { Rejected } \\
\text { (Zone } 1 \text { to 3) }\end{array}$ & Medium & Rejected & Lower & Lower & $\begin{array}{l}\text { Lower } \\
\text { (Zone } 3 \\
\text { peak) }\end{array}$ & $\begin{array}{l}\text { Rejected } \\
\text { (Zone } 1 \text { to 3) }\end{array}$ & Medium & Rejected \\
\hline
\end{tabular}


ecosystem disservices, needs to be recognised, as one element in urban ecosystems may produce both ecosystem services and ecosystem disservices that may be perceived and valued according to individual interpretations and preferences (Blanco et al., 2019, p. 3). In line with this, it is pertinent to recognise the plurality of values assigned to nature and the influence of variables such as worldviews and power dynamics in the translation of the values identified to decision-makers and stakeholders (Pascual et al., 2017, p. 14). Davoren and Shackleton (2021) further reported a dearth of research on ecosystem disservices, especially in the Global South, and emphasised the importance of mapping the distribution of those ecosystem disservices that influence human health and well-being, in the same way as ecosystem services have been mapped (e.g., Plieninger et al., 2013).

Further refinement and substantiation of the findings presented in this article should incentivise local authorities, specifically in South Africa with its contrasting results, to invest in UGSs to curate features that encourage willingness to pay for UGS proximity and address those ecosystem disservices that deter property buyers from paying more to augment revenue from property taxes. Such proceeds should be reinvested in UGSs as green infrastructure to further capitalise on valuable green assets that may deliver indispensable services and potential economic returns.

\section{Acknowledgments}

This research (or parts thereof) was made possible by the financial contribution of the National Research Foundation (NRF), South Africa (Grant No. 116243 and Grant No. 105825). Any opinion, findings, conclusions, or recommendations expressed in this material are those of the author(s). The NRF does not accept any liability in regard thereto.

\section{Conflict of Interests}

The authors declare no conflict of interests.

\section{References}

Afriyanie, D., Julian, M. M., Riqqi, A., Akbar, R., Suroso, D. S., \& Kustiwan, I. (2020). Re-framing urban green spaces planning for flood protection through socioecological resilience in Bandung City, Indonesia. Cities, 101, Article 102710.

Anderson, S. T., \& West, S. E. (2006). Open space, residential property values, and spatial context. Regional Science and Urban Economics, 36(6), 773-789.

Arvanitidis, P. A., Lalenis, K., Petrakos, G., \& Psycharis, Y. (2009). Economic aspects of urban green space: A survey of perceptions and attitudes. International Journal of Environmental Technology and Management, 11(1/3), 143-168.

Babawale, G. (2013). Valuation accuracy: The myth, expectation and reality! African Journal of Economic and Management Studies, 4(3), 387-406.

Balbi, S., Selomane, O., Sitas, N., Blanchard, R., Kotzee, I., O'Farrell, P., \& Villa, F. (2019). Human dependence on natural resources in rapidly urbanising South African regions. Environmental Research Letters, 14(4), Article 044008.

Biao, Z., Gaodi, X., Bin, X., \& Canqiang, Z. (2012). The effects of public green spaces on residential property value in Beijing. Journal of Resources and Ecology, 3(3), 243-252.

Blanco, J., Dendoncker, N., Barnaud, C., \& Sirami, C. (2019). Ecosystem disservices matter: Towards their systematic integration within ecosystem service research and policy. Ecosystem Services, 36, Article 100913.

Bolitzer, B., \& Netusil, N. R. (2000). The impact of open spaces on property values in Portland, Oregon. Journal of Environmental Management, 59(3), 185-193.

Boyer, T., \& Polasky, S. (2004). Valuing urban wetlands: A review of non-market valuation studies. Wetlands, 24(4), 744-755.

Chen, W. Y., \& Jim, C. Y. (2010). Amenities and disamenities: A hedonic analysis of the heterogeneous urban landscape in Shenzhen (China). The Geographical Journal, 176(3), 227-240.

Chen, W. Y., \& Li, X. (2018). Impacts of urban stream pollution: A comparative spatial hedonic study of high-rise residential buildings in Guangzhou, South China. The Geographical Journal, 184(3), 283-297.

Chishaleshale, M., Shackleton, C. M., Gambiza, J., \& Gumbo, D. (2015). The prevalence of planning and management frameworks for trees and green spaces in urban areas of South Africa. Urban Forestry \& Urban Greening, 14(4), 817-825.

Cilliers, E. J., \& Timmermans, W. (2013). Approaching value added planning in the green environment. Journal of Place Management and Development, 6(2), 144-154.

Cilliers, J. (2013). Ekonomiese waarde van groen ruimtes: Suid-Afrika in kontras met Europa [Economic value of green spaces: South Africa in contrast with Europe]. Acta Academica, 45(3), 99-125.

Cilliers, J., \& Cilliers, S. (2015). From green to gold: A South African example of valuing urban green spaces in some residential areas in Potchefstroom. Town and Regional Planning, 67, 1-12.

Cilliers, S. S., Breed, C. A., Cilliers, E. J., \& Lategan, L. G. (2021). Urban ecological planning and design in the Global South. In C. M. Shackleton, S. Cilliers, E. Davoren, \& M. du Toit (Eds.), Urban ecology in the Global South (pp. 365-401). Springer.

Cilliers, S., Cilliers, J., Lubbe, R., \& Siebert, S. (2013). Ecosystem services of urban green spaces in African countries-Perspectives and challenges. Urban Ecosystems, 16(4), 681-702.

Combrinck, Z. (2020). Reclaiming nature in cities: An eco- 
nomic valuation approach across the socio-economic gradient in Potchefstroom [Unpublished Master's thesis, North-West University].

Combrinck, Z., Cilliers, E. J., Lategan, L., \& Cilliers, S. (2020). Revisiting the proximity principle with stakeholder input: Investigating property values and distance to urban green space in Potchefstroom. Land, 9(7), Article 235.

Conway, D., Li, C. Q., Wolch, J., Kahle, C., \& Jerrett, M. (2010). A spatial autocorrelation approach for examining the effects of urban greenspace on residential property values. The Journal of Real Estate Finance and Economics, 41(2), 150-169.

Crompton, J. L. (2005). The impact of parks on property values: Empirical evidence from the past two decades in the United States. Managing Leisure, 10(4), 203-218.

Crompton, J. L., \& Nicholls, S. (2020). The impact on property values of golf courses in the United States. Journal of Park and Recreation Administration, 38(2).

Cypher, M., \& Hansz, J. A. (2003). Does assessed value influence market value judgments? Journal of Property Research, 20(4), 305-318.

Czembrowski, P., Łaszkiewicz, E., Kronenberg, J., Engström, G., \& Andersson, E. (2019). Valuing individual characteristics and the multifunctionality of urban green spaces: The integration of sociotope mapping and hedonic pricing. PloS One, 14(3), Article e0212277.

Daams, M. N., Sijtsma, F. J., \& Veneri, P. (2019). Mixed monetary and non-monetary valuation of attractive urban green space: A case study using Amsterdam house prices. Ecological Economics, 166, Article 106430.

Das, N. C., \& Thappa, S. (2018). A study on valuation of real estate property within Guwahati Metropolitan City Area. CLEAR International Journal of Research in Commerce \& Management, 9(5).

Davoren, E., \& Shackleton, C. M. (2021). Urban ecosystem disservices in the Global South. In C. M. Shackleton, S. Cilliers, E. Davoren, \& M. du Toit (Eds.), Urban ecology in the Global South (pp. 265-292). Springer.

Dehring, C., \& Dunse, N. (2006). Housing density and the effect of proximity to public open space in Aberdeen, Scotland. Real Estate Economics, 34(4), 553-566.

du Toit, M. J., Cilliers, S. S., Dallimer, M., Goddard, M., Guenat, S., \& Cornelius, S. F. (2018). Urban green infrastructure and ecosystem services in sub-Saharan Africa. Landscape and Urban Planning, 180, 249-261.

Escobedo, F. J. (2021). Understanding urban regulating ecosystem services in the Global South. In C. M. Shackleton, S. Cilliers, E. Davoren, \& M. du Toit (Eds.), Urban ecology in the Global South (pp. 227-244). Springer.

Garcia-Garcia, M. J., Christien, L., García-Escalona, E., \& González-García, C. (2020). Sensitivity of green spaces to the process of urban planning. Three case studies of Madrid (Spain). Cities, 100, Article 102655.
Ghyoot, V. G. (2008). The accuracy of the Johannesburg provisional valuation roll, 2001. Management Dynamics: Journal of the Southern African Institute for Management Scientists, 17(2), 2-13.

Gibbons, S., Mourato, S., \& Resende, G. M. (2014). The amenity value of English nature: A hedonic price approach. Environmental and Resource Economics, 57(2), 175-196.

Girma, Y., Terefe, H., Pauleit, S., \& Kindu, M. (2019). Urban green spaces supply in rapidly urbanizing countries: The case of Sebeta Town, Ethiopia. Remote Sensing Applications: Society and Environment, 13, 138-149.

Gómez-Baggethun, E., \& Barton, D. N. (2013). Classifying and valuing ecosystem services for urban planning. Ecological Economics, 86, 235-245.

Grafius, D. R., Corstanje, R., \& Harris, J. A. (2018). Linking ecosystem services, urban form and green space configuration using multivariate landscape metric analysis. Landscape Ecology, 33(4), 557-573.

Hager, D. P., \& Lord, D. J. (1985). The property market, property valuations and property performance measurement. Journal of the Institute of Actuaries, 112(1), 19-60.

Immergluck, D., \& Balan, T. (2018). Sustainable for whom? Green urban development, environmental gentrification, and the Atlanta beltline. Urban Geography, 39(4), 546-562.

Jacobs, N. S. (2019). Planning sustainable cities through nature-based solutions: Perspectives from the Global South [Master's thesis, North-West University]. Boloka Institutional Repository.

Janssen, C., \& Söderberg, B. (1999). Estimating market prices and assessed values for income properties. Urban Studies, 36(2), 359-376.

Kim, Y. S., \& Johnson, R. L. (2002). The impact of forests and forest management on neighboring property values. Society \& Natural Resources, 15(10), 887-901.

Kong, F., Yin, H., \& Nakagoshi, N. (2007). Using GIS and landscape metrics in the hedonic price modeling of the amenity value of urban green space: A case study in Jinan City, China. Landscape and Urban Planning, 79(3/4), 240-252.

Konijnendijk, C. C., Annerstedt, M., Maruthaveeran, S., \& Nielsen, A. B. (2013). Benefits of urban parks: A systematic review. International Federation of Parks and Recreation Administration.

Kovacs, K. F. (2012). Integrating property value and local recreation models to value ecosystem services from regional parks. Landscape and Urban Planning, 108(2/4), 79-90.

Lategan, L. G., \& Cilliers, J. E. (2016a). Towards more compact South African settlements through informal housing: The case of backyard densification in Bridgton and Bongolethu, Oudtshoorn. Town and Regional Planning, 68, 12-26.

Lategan, L. G., \& Cilliers, J. E. (2016b). Considering urban green space and informal backyard rentals in 
South Africa: Disproving the compensation hypothesis. Town and Regional Planning, 69, 1-16.

Lategan, L. G., Erasmus, S., Zietsman, M., Cilliers, E. J., Wolf, M., \& Springer, C. A. (2020). Risking health for rental housing: Reviewing service access in the informal backyard rental sector. Jàmbá: Journal of Disaster Risk Studies, 12(1), 1-11.

Loret de Mola, U., Ladd, B., Duarte, S., Borchard, N., Anaya La Rosa, R., \& Zutta, B. (2017). On the use of hedonic price indices to understand ecosystem service provision from urban green space in five Latin American megacities. Forests, 8(12), Article 478.

Lubbe, C. S. (2011). Comparison of the urban domestic garden flora along a socio-economic gradient in the Tlokwe City municipality [Doctoral dissertation, North-West University]. Boloka Institutional Repository.

Lubbe, C. S., Siebert, S. J., \& Cilliers, S. S. (2010). Political legacy of South Africa affects the plant diversity patterns of urban domestic gardens along a socioeconomic gradient. Scientific Research and Essays, 5(19), 2900-2910.

Malaitham, S., Fukuda, A., Vichiensan, V., \& Wasuntarasook, V. (2020). Hedonic pricing model of assessed and market land values: A case study in Bangkok metropolitan area, Thailand. Case Studies on Transport Policy, 8(1), 153-162.

Morancho, A. B. (2003). A hedonic valuation of urban green areas. Landscape and Urban Planning, 66(1), 35-41.

Nicholls, S., \& Crompton, J. L. (2007). The impact of a golf course on residential property values. Journal of Sport Management, 21(4), 555-570.

Ntuli, N. (2019, August 12). Msunduzi valuations roll in turmoil. The Witness. www.news24.com/amp/ witness/news/msunduzi-valuations-roll-in-turmoil20190812

Nyabwengi, L. (2020). An evaluation of the property valuation process for County Government Property Taxation, Nairobi City. Africa Habitat Review, 14(1), 1731-1743.

Panduro, T. E., \& Veie, K. L. (2013). Classification and valuation of urban green spaces-A hedonic house price valuation. Landscape and Urban planning, 120, 119-128.

Pascual, U., Balvanera, P., Díaz, S., Pataki, G., Roth, E., Stenseke, M., Watson, R. T., Sessane, E. B., Islar, M., Kelemen, E., Maris, V., Quass, M., Subramanian, S. M., Wittmer, H., Adlan, A., Ahn, S., Yousef, S. A., Anankwah, D., Asah, S. T., ... Yagi, N. (2017). Valuing nature's contributions to people: The IPBES approach. Current Opinion in Environmental Sustainability, 26, 7-16.

Pauleit, S., Vasquéz, A., Maruthaveeran, S., Liu, L., \& Cilliers, S. S. (2021). Urban green infrastructure in the Global South. In C. M. Shackleton, S. Cilliers, E. Davoren, \& M. du Toit (Eds.), Urban ecology in the Global South (pp. 107-143). Springer.
Payton, S., Lindsey, G., Wilson, J., Ottensmann, J. R., \& Man, J. (2008). Valuing the benefits of the urban forest: A spatial hedonic approach. Journal of Environmental Planning and Management, 51(6), 717-736.

Plieninger, T., Dijks, S., Oteros-Rozas, E., \& Bieling, C. (2013). Assessing, mapping, and quantifying cultural ecosystem services at community level. Land Use Policy, 33, 118-129.

Property24. (2021). Potchefstroom property trends and statistics. www.property24.com/potchefstroom/ property-trends/ 125

Ramakhula, M. (2010). Implications of the Municipal Property Rates Act (No: 6 of 2004) on municipal valuations [Master's thesis, University of the Witwatersrand]. Wits Institutional Repository.

Samad, N. S. A., Abdul-Rahim, A. S., Yusof, M. J. M., \& Tanaka, K. (2020). Assessing the economic value of urban green spaces in Kuala Lumpur. Environmental Science and Pollution Research, 27(10), 10367-10390.

Shackleton, C. M., Cilliers, S. S., du Toit, M. J., \& Davoren, E. (2021). The need for an urban ecology of the Global South. In C. M. Shackleton, S. Cilliers, E. Davoren, \& M. du Toit (Eds.), Urban ecology in the Global South (pp. 1-26). Springer.

Sharmin, F. (2020). Towards the valuation of open spaces: A hedonic based investigation for sustainable planning in the dense urban context of Dhaka. American Journal of Environmental and Resource Economics, 5(4), 97-103.

Sokutu, B. (2021, May 31). Residents up in arms over Ekurhuleni's property roll. The Citizen. https://citizen. co.za/news/south-africa/government/2508387/ residents-up-in-arms-over-ekurhulenis-property-roll

Steenkamp, J., Cilliers, E. J., Cilliers, S. S., \& Lategan, L. (2021). Food for thought: Addressing urban food security risks through urban agriculture. Sustainability, 13(3), Article 1267.

Tajima, K. (2003). New estimates of the demand for urban green space: Implications for valuing the environmental benefits of Boston's big dig project. Journal of Urban Affairs, 25(5), 641-655.

Van Oijstaeijen, W., Van Passel, S., \& Cools, J. (2020). Urban green infrastructure: A review on valuation toolkits from an urban planning perspective. Journal of Environmental Management, 267, Article 110603.

Van Zyl, B. (2021). The integration of urban planning and urban ecology: Investigating multi-functionality and ecosystem services [Master's thesis, North-West University]. Boloka Institutional Repository.

Venter, Z. S., Shackleton, C. M., Van Staden, F., Selomane, O., \& Masterson, V. A. (2020). Green Apartheid: Urban green infrastructure remains unequally distributed across income and race geographies in South Africa. Landscape and Urban Planning, 203, Article 103889.

Wen, H., Zhang, Y., \& Zhang, L. (2015). Assessing amenity effects of urban landscapes on housing price in 
Hangzhou, China. Urban Forestry \& Urban Greening, 14(4), 1017-1026.

Yates, S. R., \& Cowart, L. B. (2019). The impact of shuttered golf courses on property values. Journal of Sustainable Real Estate, 11(1), 2-15.
Yu, Y., Zhang, W., Fu, P., Huang, W., Li, K., \& Cao, K. (2020). The spatial optimization and evaluation of the economic, ecological, and social value of urban green space in Shenzhen. Sustainability, 12(5), Article 1844.

\section{About the Authors}

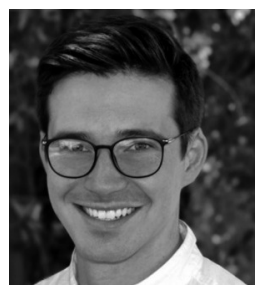

Louis Lategan holds a PhD in urban and regional planning from the North-West University, South Africa where he is currently employed as a senior lecturer by extraordinary appointment in the Unit for Environmental Sciences and Management. His research in urban and regional planning focuses on urban sustainability in the Global South, specifically investigating low-income housing, informal rentals, and green urbanism. He is a registered professional planner with the South African Council for Planners.

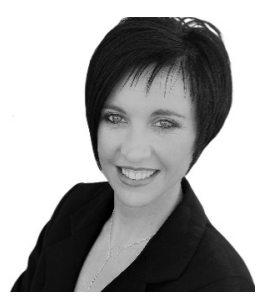

Juaneé Cilliers is head of the School of Built Environment, and professor of urban planning at the Faculty of Design, Architecture and Building at the University of Technology Sydney (Australia). She has professional registrations from both the South African Council for Planners (SACPLAN) and the Planning Institute of Australia (PIA). She is currently appointed as extraordinary professor of planning at the North-West University (South Africa), and is the chair of the Women in Planning Network of the Commonwealth Association of Planners.

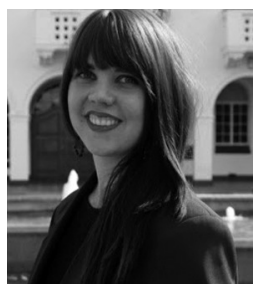

Zinea Huston completed her undergraduate degree in urban and regional planning in 2016 at the North-West University, South Africa and went on to obtain her Master's in the same field. She is currently pursuing a PhD with specific focus on the teaching-learning methodologies within the spatial planning paradigm.

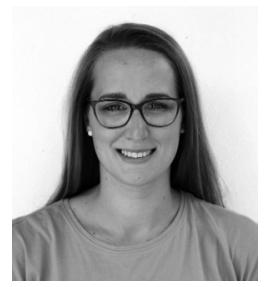

Nadia Blaauw recently graduated with a degree in urban and regional planning from the North-West University, South Africa. Her final research project in fulfillment of the requirements for her degree focussed on the economic value of green spaces in Potchefstroom, South Africa. She is currently completing an internship at an environmental consultancy firm in Potchefstroom.

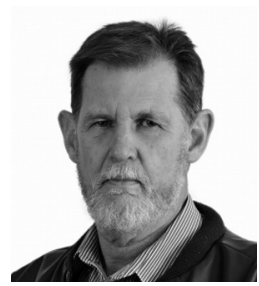

Sarel Cilliers is professor of plant ecology at the North-West University, South Africa with research and teaching experience spanning 33 years. His research focuses on urban ecology, especially biodiversity and ecosystem services along socio-economic and urbanization gradients. He serves on the editorial boards of four international journals that publish urban ecological research. He participates in several international projects in urban ecology, e.g., co-founder and on steering committee of a global network (UrBioNet), supporting urban biodiversity research monitoring and practice, and a Global Urban Soil Ecology and Education Network (GLUSEEN). 